\title{
Ibrutinib in B-cell lymphoma: single fighter might be enough?
}

\author{
Chao Xue ${ }^{1}$, Xin Wang ${ }^{1,2,3}$, Lingyan Zhang ${ }^{3}$, Qingyuan Qu', Qian Zhang ${ }^{3}$ and Yujie Jiang ${ }^{3^{*}}$ (1)
}

\begin{abstract}
Background: In recent years, the B cell receptor (BCR) signaling pathway has become a "hot point" because it plays a critical role in B-cell proliferation and function. Bruton's tyrosine kinase (BTK) is overexpressed in many subtypes of B-cell lymphoma as a downstream kinase in the BCR signaling pathway. Ibrutinib, the first generation of BTK inhibitor, has shown excellent antitumor activity in both indolent and aggressive B-cell lymphoma.

Main body: Ibrutinib monotherapy has been confirmed to be effective with a high response rate (RR) and welltolerated in many B-cell lymphoma subgroups. To achieve much deeper and faster remission, combination strategies contained ibrutinib were conducted to evaluate their synergistic anti-tumor effect.

Conclusions: For patients with indolent B-cell lymphoma, most of them respond well with ibrutinib monotherapy. Combination strategies contained ibrutinib might be a better choice to achieve deeper and faster remission in the treatment of aggressive subtypes of B-cell lymphoma. Further investigations on the long-term efficacy and safety of the ibrutinib will provide novel strategies for individualized treatment of B-cell lymphoma.
\end{abstract}

Keywords: B-cell lymphoma, B cell receptor (BCR) signaling pathway, Bruton's tyrosine kinase (BTK), Ibrutinib, Monotherapy

\section{Background}

Among lymphatic malignancies, B-cell lymphoma is the most common type, accounting for $85 \%$ of non-Hodgkin lymphoma (NHL). It has been confirmed that the B cell receptor (BCR) signaling pathway, once revealed in 1993, plays an important role in the occurrence and development of B-cell lymphomas [1]. Bruton's tyrosine kinase (BTK) is a downstream kinase that plays a central regulatory role in the BCR pathway [2]. Ibrutinib, the firstgeneration BTK inhibitor, has shown excellent antitumor activity in both indolent and aggressive B-cell lymphoma.

In recent decades, the efficacy and safety of ibrutinib monotherapy or combined with other agents have been

\footnotetext{
*Correspondence: yujiejiang05@126.com

${ }^{3}$ Department of Hematology, Shandong Provincial Hospital Affiliated

to Shandong First Medical University, No.324, Jingwu Road, 250021 Jinan, Shandong, China

Full list of author information is available at the end of the article
}

explored in different subtypes of B-cell lymphomas [3, 4]. Even ibrutinib monotherapy has been the first-line treatment for some patients suffering symptomatic chronic lymphocytic lymphoma/small lymphocytic lymphoma (CLL/SLL) or elder/frail patients with primary central nervous system lymphoma (PCNSL) who can not endure high-dose methotrexate $[5,6]$. Ibrutinib monotherapy might be enough for them to have a better life quality with well disease control. Furthermore, many researchers tried to combine BTK inhibitors with other agents to achieve deeper and faster remission. In this review, we will focus on the clinical progression and compare the efficacy of ibrutinib monotherapy or combination strategies for the treatment of B-cell lymphoma based on some ongoing or just-completed clinical trials.

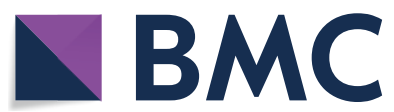

(c) The Author(s) 2020. This article is licensed under a Creative Commons Attribution 4.0 International License, which permits use, sharing, adaptation, distribution and reproduction in any medium or format, as long as you give appropriate credit to the original author(s) and the source, provide a link to the Creative Commons licence, and indicate if changes were made. The images or other third party material in this article are included in the article's Creative Commons licence, unless indicated otherwise in a credit line to the material. If material is not included in the article's Creative Commons licence and your intended use is not permitted by statutory regulation or exceeds the permitted use, you will need to obtain permission directly from the copyright holder. To view a copy of this licence, visit http://creativeco mmons.org/licenses/by/4.0/. The Creative Commons Public Domain Dedication waiver (http://creativecommons.org/publicdomain/ zero/1.0/) applies to the data made available in this article, unless otherwise stated in a credit line to the data. 


\section{Bruton's Tyrosine Kinase (BTK) and associated cross-linking signaling pathways}

BTK is a nonreceptor tyrosine kinase of the TEC family that comprises five structural domains. It is continuously activated in B-cell lymphoma as a key mediator in tumor cell survival [7]. Following antigen binding to the extracellular part of BCR, activated BTK plays an essential signaling role in the $\mathrm{BCR}$ downstream pathway, which can regulate multiple cellular proliferation, differentiation, and apoptosis functions by cross-linking, activating many crucial proteins and pathways. These small-molecule BTK inhibitors irreversibly block its enzymatic activity by covalently bonding to the particular Cys-481 within the ATP binding pocket of BTK (Fig. 1a). BTK inhibitors not only inhibit the BCR signaling pathway, but also inhibit other downstream pathways including NF-kB, MAPK, NFAT, and mTOR pathways. The inhibition of those cross-linking pathways results in the activation of antitumor $\mathrm{T}$ cells and eventually the tumor eradication (Fig. 1b). Overall, BTK inhibitors involved not only in the BCR pathway but also in multiple important signaling pathways that closely related to $\mathrm{B}$ cell proliferation. This might

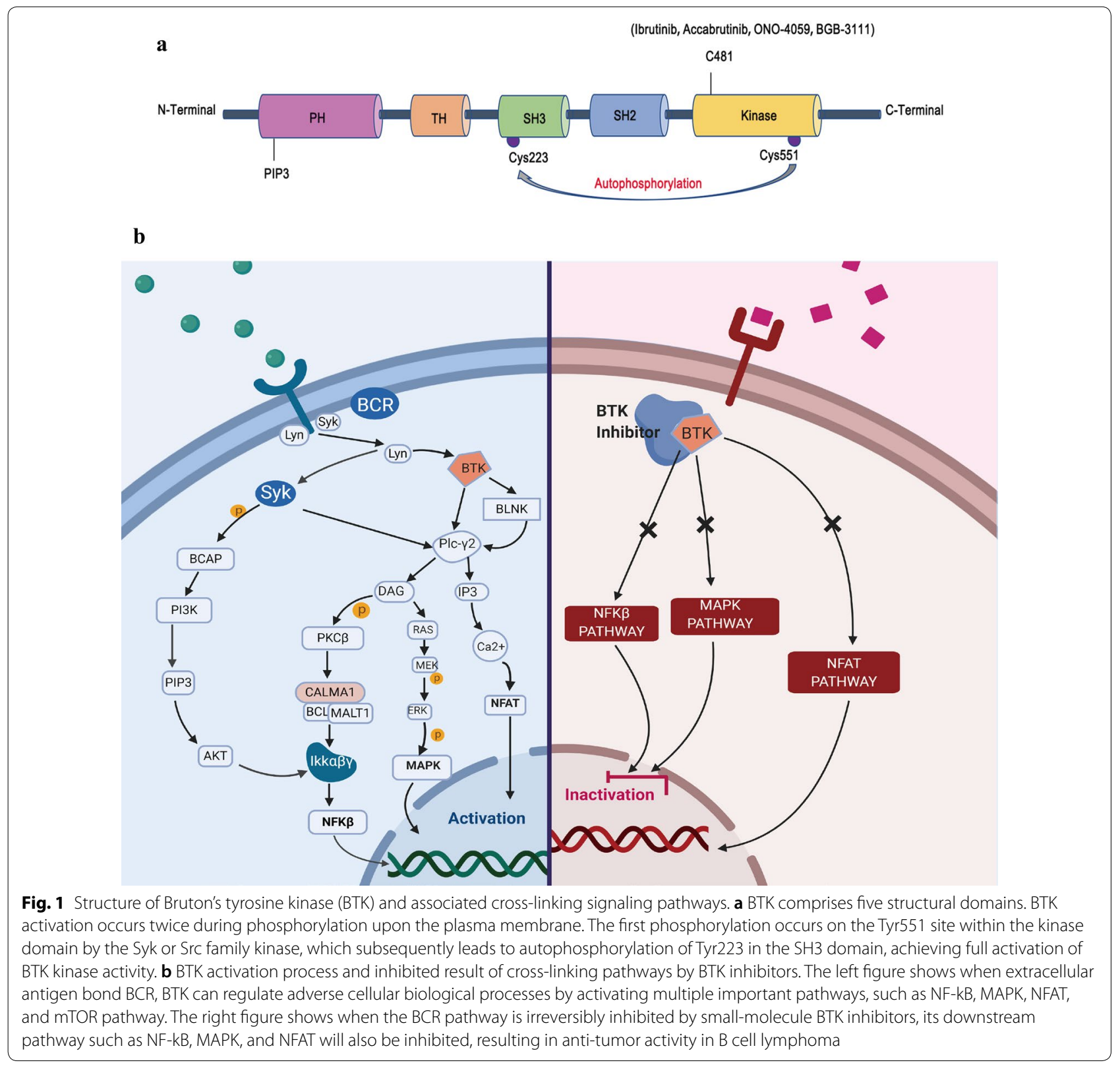


interpret its powerful and high-effective inhibition effect in the treatment of B-cell lymphoma.

\section{Ibrutinib monotherapy in B-cell lymphoma}

As a first-generation BTK inhibitor, ibrutinib was rapidly approved by the US Food and Drug Administration (FDA) for the treatment of CLL/SLL and MCL (mantle cell lymphoma) in 2014 and 2013, respectively. It was continuously approved for use as a single agent in patients with lymphoplasmacytic lymphoma (LPL)/ WM (Waldenstrom's macroglobulinemia) and marginal zone lymphoma (MZL) in 2015 and 2017, respectively [8]. Ibrutinib monotherapy exhibits a powerful antitumor effect and this magical small-molecular drug was honored with the "Prix Gallen Award" in 2015. In some subtypes of B-cell lymphoma, ibrutinib monotherapy has been confirmed to be enough to induce a satisfying response rate (RR). Here, we summarized the results of the available completed or ongoing clinical/preclinical trials of ibrutinib monotherapy (Table 1).

\section{Ibrutinib monotherapy in relapsed/refractory (R/R) and treatment-native (TN) CLL/SLL}

Before the ibrutinib era, monotherapy strategies for the treatment of CLL/SLL include chlorambucil, rituximab, or bendamustine. Rituximab combined with the nucleoside analog (fludarabine) and cyclophosphamide (R-FC) regimen has been the standard treatment for the patient with CLL/SLL who meet the criteria to start treatment [9]. Although long-term disease-free survival (DFS) and durable remission can be achieved in many patients, the prognosis of some elderly patients or patients with deletion $17 \mathrm{p}(17 \mathrm{p}-)$ is still unsatisfactory due to chemotherapy-related toxicity and poor response to the above agents. The accurate mechanism for the development of $\mathrm{R} / \mathrm{R}$ CLL/SLL is still unknown and $17 \mathrm{p}-$ has been recognized as the most important adverse prognostic factor $[10,11]$. In the pre-ibrutinib era, the overall survival (OS) of patients with $17 \mathrm{p}-$ is only approximately $38 \%$. Allogeneic stem cell transplantation (allo-SCT) was performed in an eligible patient. However, transplantation-related morbidity (TRM) remains an obstacle to achieving longterm survival. Some elderly or frail patients have no chance of receiving allo-SCT.

The occurrence of ibrutinib significantly changed this situation and the data came from real-world settings indicated that ibrutinib can overcome the adverse effect of the p53 mutation to some extent [12]. The possible reason to interpret the mechanism of ibrutinib on the p53 mutation might be that ibrutinib does not require a fully functional p53 pathway. In other words, ibrutinib plays its role regardless of p53 mutation status [4].
Until 2019, the largest scale study about ibrutinib in patients with $17 \mathrm{p}$ - was reported by Jones and his colleagues. They evaluated the outcomes in 230 patients with $\mathrm{R} / \mathrm{R} 17 \mathrm{p}-\mathrm{CLL} / \mathrm{SLL}$ from three ibrutinib studies. With a median follow-up of 28 months, OS was $57 \%$, the estimated 30-month progression-free survival (PFS) and OS were $57 \%$ and $69 \%$, respectively [1]. Another study reported by Byrd et al. described the efficacy of ibrutinib monotherapy of the 7-year follow-up in $R / R$ CLL/SLL patients with other unfavorable cytogenetic mutations [13]. Among 132 patients, 101 were R/R disease with del 17p (34\%), del 11q (35\%), del 13q (47\%), and unmutated IGVH (78\%), respectively. A durable response with an overall response rate (ORR) of $89 \%$ was maintained in all the patients and the median duration of response was 57 months in R/R patients, providing the evidence overcoming the influence of adverse cytogenetic abnormalities with ibrutinib. Furthermore, Byrd et al. conducted a controlled phase 3 study to evaluate the efficacy of ibrutinib in CLL/SLL patients at risk for a poor outcome (a short duration of response to efficacy or adverse cytogenetic abnormalities) by comparing ibrutinib with ofatumumab (a humanized antiCD20 monoclonal antibody). The data indicated that ibrutinib has significantly higher single-agent efficacy in contrast to ofatumumab (ORR $42.6 \%$ vs. $4.1 \%$, OS $90 \%$ vs. $80 \%$ ) [14].

Based on the previous clinical data in R/R CLL/SLL, ibrutinib monotherapy is more effective and tolerant compared with other agents. Therefore, many researchers tried to use ibrutinib in patients with TN CLL/SLL. In a phase $1 \mathrm{~b} / 2$ study, ibrutinib monotherapy was given to patients with TN CLL/SLL aged at least 65 years old [15]. The patients received 28-day cycles of once-daily ibrutinib at a dose of $420 \mathrm{mg}$ or $840 \mathrm{mg}$. Seventy percent $(22 / 31)$ patients achieved an objective response, including 4 complete response (CR), 1 nodular partial response, and 17 partial response (PR). Another phase 3 trial was conducted by Beuger and his colleagues comparing ibrutinib with chlorambucil in patients with TN CLL/SLL [3]. Their results indicated that compared with chlorambucil, ibrutinib showed a significantly superior in terms of PFS, OS, and RR (not reached vs. 18.9 months, $98 \%$ vs. $85 \%, 86 \%$ vs. $35 \%$ ), respectively. Therefore, ibrutinib monotherapy in TN CLL/SLL also exhibited an effective and tolerable response as anticipated, especially in elderly patients.

Taken together, the numerous results from the existing clinical trials indicated that single-agent therapy with ibrutinib could be chosen as the first-line recommendation for both TN and R/R CLL/SLL patients with a durable response and well tolerance. 


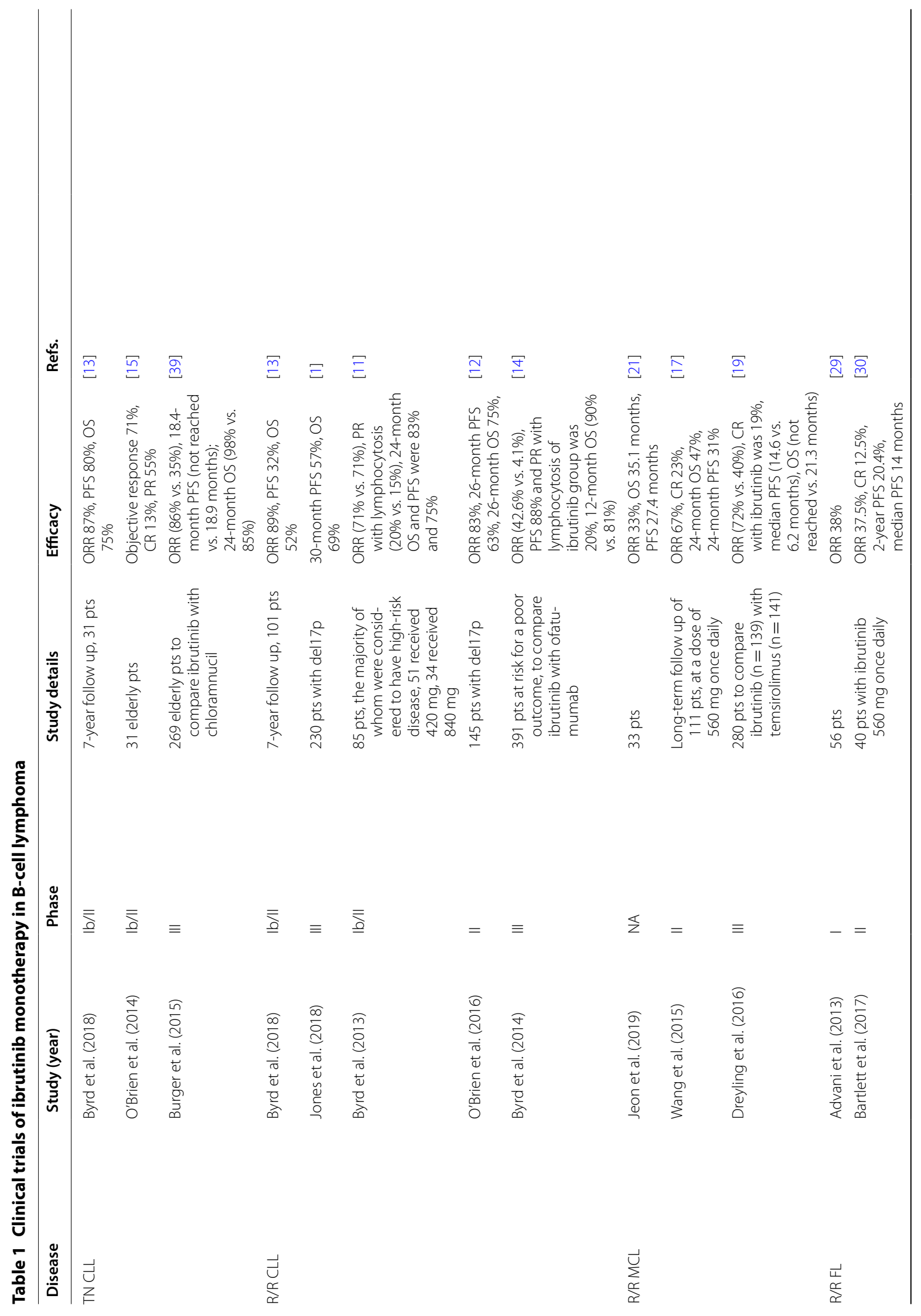




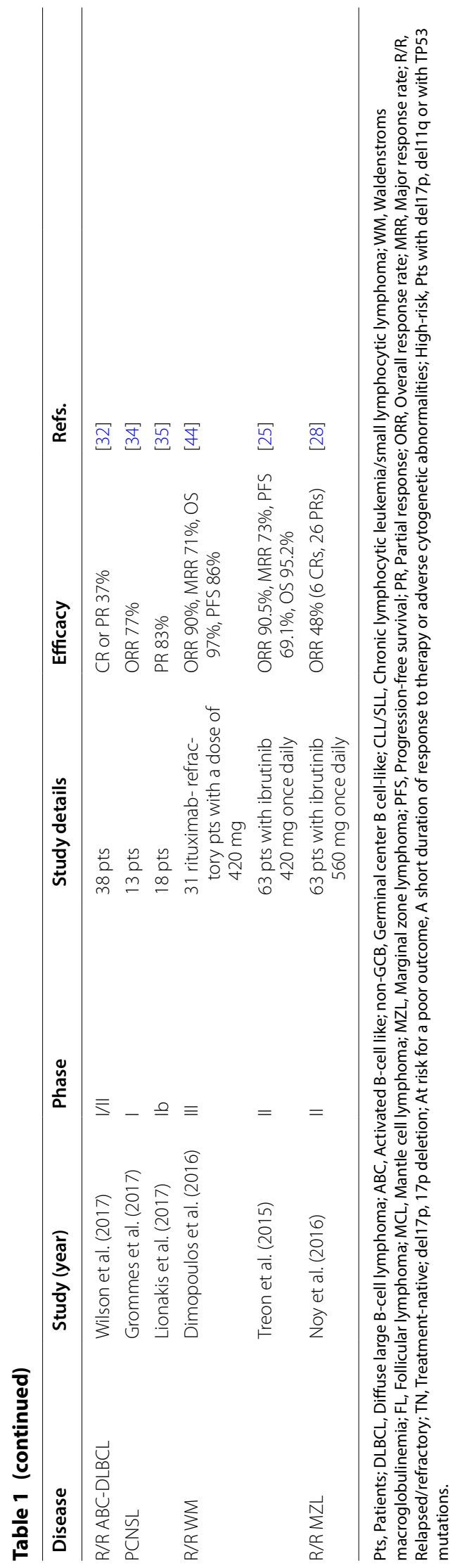




\section{Ibrutinib monotherapy in MCL}

MCL is a heterogeneous subtype of NHL and some patients will relapse after short-term remission. With the improved understanding of molecular pathophysiology in MCL, some important signaling pathways, including BTK, NF- $\mathrm{B}$, and PI3K, have been extensively investigated in both MCL cell lines and biopsy samples of patients with MCL [16]. Until now, most of the clinical trials of ibrutinib in MCL were conducted in $R / R$ disease. Wang et al. conducted a phase 2 study that enrolled 111 (median age of 68 years) patients with R/R MCL [17]. In this study, patients were enrolled into two sub-groups: those who had previously received $\geq$ 2 cycles and those received $0 \sim 1$ cycle of bortezomib therapy. Single-agent ibrutinib was administered at a daily dose of $560 \mathrm{mg}$. The RR, CR, and PR was $68 \%$, $21 \%$, and $47 \%$, respectively. They also observed that prior treatment with bortezomib had no effect on the $\mathrm{RR}$ and the estimated OS was $58 \%$ at 18 months [18].

Temsirolimus, an mTOR inhibitor, has been approved for the treatment of patients with R/R MCL in ESMO (European Society of Medical Oncology) guidelines. However, it is usually accompanied by adverse events (AEs) such as thrombocytopenia, anemia, fatigue, and diarrhea. Drying et al. conducted a phase 3 clinical trial to assess the efficacy and safety of ibrutinib versus temsirolimus in patients with R/R MCL [19]. A significantly longer PFS, ORR, and CR in ibrutinib than that in the temsirolimus group (14.6 months vs. 6.2 months, $72 \%$ vs. $40 \%, 19 \%$ vs. $1 \%$ ) have been observed in the primary efficacy analysis. Also, ibrutinib was better tolerated than temsirolimus with fewer discontinuations owing to AEs (6\% vs. $26 \%$ ). In nowadays, more ongoing clinical trials are accessing ibrutinib's efficacy as the firstline treatment in newly diagnosed MCL, especially for those ineligible for autologous stem cell transplantation (ASCT) at the first remission stage [20].

Unlike ibrutinib monotherapy in CLL/SLL, it might not be enough for patients with MCL. A real-world study indicated a median OS and PFS after ibrutinib monotherapy in $\mathrm{R} / \mathrm{R}$ MCL patients were 35.1 months and 27.4 months, respectively [21]. This might be interpreted by the biological differences and more complex cross-action signaling pathways in MCL patients. Therefore, ibrutinib monotherapy might not be the best choice for this population and other choices such as combination strategies followed by stem cell transplantation might be favorable for them [21].

\section{Ibrutinib monotherapy in WM/LPL}

Quite an amount of patients with WM/LPL can be employed "watchful waiting" until they meet the criteria to begin treatment, while some high-risk patients will refractory to rituximab or bortezomib contained chemotherapy regimen [22]. The myeloid differentiation primary response 88 (MYD88) mutation is highly prevalent in approximately $90 \%$ of patients with WM, which triggers the growth of tumor cells through BTK involved in the NF- $\mathrm{kB}$ pathway [23]. Therefore, ibrutinib will also theoretically be effective for patients with WM/LPL. A phase 3 clinical trial was conducted to assess the activity of ibrutinib in patients with rituximab-refractory WM [24]. As for 31 patients, most of them achieved a high ORR (90\%), sustainable estimated median PFS (86\%), and OS (97\%). Many researchers predict that WM/LPL patients with the MYD88 mutation will benefit from ibrutinib compared with wild type MYD88. A report confirmed that patients with MYD $88^{\text {wt }}$ and CXCR $4^{\text {mut }}$ have a poor response to ibrutinib, however, the existing follow-up data show that some patients will still benefit from ibrutinib in the long-term, the accurate mechanism needed to be discussed in more studies [25-27]. Overall, preliminary data indicate that ibrutinib monotherapy is a potential new treatment choice for patients with newly diagnosed or R/R WM/LPL.

\section{Ibrutinib monotherapy in MZL and follicular lymphoma (FL)}

MZL is a group of indolent B-cell lymphomas that originated from marginal zone B cells present in lymph nodes and extranodal tissues. MZL is associated with a variety of chronic infections, such as Helicobacter pylori, hepatitis virus $C$, and parrot chlamydia. Continuous antigen stimulation can activate the BCR signaling pathway, resulting in aberrant $B$ cell abnormal hyperplasia and implicating BTK as a potential target in this malignancy. Ibrutinib may be an ideal candidate for MZL through blocking BTK, yielding a high clinical benefit rate, and clinically meaningful tumor shrinkage. The limited preliminary clinical results indicate a satisfactory profile of high ORR and durable responses. A multicenter, openlabel, phase 2 study evaluated the efficacy and safety of ibrutinib in R/R MZL [28]. Among the 63 enrolled patients, PFS was 18 months after a median follow-up of 19.4 months, and the ORR was $51 \%$. Subsequently, the outcomes were also analyzed by the MZL subtype. The median PFS was 13.8, 19.4, and 8.3 months for EMZL (extranodal MZL), SMZL (splenic MZL), and NMZL (nodal MZL), respectively. Therefore, ibrutinib was accelerated by the FDA for the treatment of R/R MZL in 2017, 
and it might be an effective, chemotherapy-free, targeted strategy option for this population.

Although typically indolent, FL remains an incurable disease. Some patients with FL will develop R/R disease and even transform into aggressive subtype NHL, such as diffuse large B-cell lymphoma (DLBCL) [29]. Based on the encouraging experience with other B-cell lymphomas, researchers applied ibrutinib to the treatment of FL. However, single-agent ibrutinib is not promising in both untreated or R/R FL patients. In a phase 2 study in R/R FL, ibrutinib produced an ORR $37.5 \%$, CRR $12.5 \%$, and a 2 -year PFS $20.4 \%$, these data showed no significant benefit compared with R-CHOP regimen [30]. The reason for the inefficiency of ibrutinib monotherapy in patients with FL remains unclear. The malignant cell origin, BCR signaling inhibition site, and other signaling pathways involved in the pathogenesis and development of FL might explain this result. Until now, rituximab contained regimen or rituximab maintenance is still recommended as the first-line treatment choice for FL patients. So more randomized pilots are needed to evaluate the potency of BTK inhibitors for patients with FL. Several explorations of BTK inhibitors for the treatment of FL are underway and a definitive conclusion has not been drawn yet.

\section{Ibrutinib monotherapy in DLBCL}

DLBCL is the most common subtype of B-cell malignancy, accounting for 30 to $40 \%$ of all cases. Activated B cell-like $(A B C)$ and germinal center $B$ cell-like (GCB) are two major subtypes of DLBCL that are induced by distinct mechanisms. The prognosis of the $\mathrm{ABC}$ subtype is usually worse than that of GCB. However, patients in the $A B C$ type can benefit from ibrutinib because malignant $B$ cells in the $A B C$ subtype selectively acquire mutations by targeting the $B C R$ to foster chronic active $B C R$ signaling [31]. In a phase $1 / 2$ clinical study in which 20 patients were enrolled, ibrutinib monotherapy produced $R R$ in $37 \%$ of $\mathrm{ABC}$ cases but only $5 \%$ in patients with GCBDLBCL. Furthermore, the most noticeable RR $(80 \%)$ was observed in tumors with concomitant MYD88 and BCRassociated protein CD79B mutations. This is consistent with the response of ibrutinib in LPL/WM. However, this does not explain the whole situation. A higher response also occurred within $\mathrm{ABC}$ tumors that lacked BCR mutations, suggesting that oncogenic $B C R$ signaling in $A B C$ might not require $\mathrm{BCR}$ mutations and may be initiated by nongenetic mechanisms [32]. Nevertheless, the accurate mechanism of BTK inhibitor resistance and less response in other subtypes of DLBCL need further investigation.

Primary or secondary central nervous system lymphoma (PCNSL/SCNSL) is a rare subtype of extranodal lymphoma, with a very poor prognosis and a median survival of only 2 months without additional treatment. Most of the histological types of PNCSLs are DLBCL and high-dose methotrexate (MTX)-based regimens are recognized as the first-line treatment choice [33]. However, the cure rate remains below $40 \%$, and the tumor is prone to late recurrences. When recurrences develop, the patients often fail to respond to the former therapy and progress quickly. Novel insights into the pathogenesis of PCNSL indicate that PCNSL harbors mutations of hyperactive BCR signaling. Grommes et al. performed a phase 1 clinical study to evaluate the tolerability of ibrutinib monotherapy in 20 patients with R/R CNSL [34]. A total of 77\% (10/13, 5 CR, 5 PR) of patients with PSCNL and 71\% (5/7, 4 CR) of patients with SCNSL represented a clinical response. The median PFS was 4.6 and 7.43 months in PCNSL and SCNCL, respectively. Their clinical data and genomic analysis indicated that the differences between the two types might be due to the distinguishing features of BTK dependence and BCR pathway mutations. Interestingly, this study also found that the anti-tumor activity of ibrutinib in R/R PCNSL is much higher than that in patients with $\mathrm{R} / \mathrm{R}$ DLBCL outside the CNS (ORR $77 \%$ vs. $25 \%$, OS 15 months vs. 6.4 months). This may be because MYD88 and CD79B mutations are more common in PCNSL than in DLBCL outside the CNS, and the brain microenvironment might promote BTK dependence through chronic antigen expression and BTK activation. Meanwhile, these data suggest that further studies are needed to determine how genetic and tumor microenvironment factors, alone or in combination, create intrinsic BTK dependence in different B-cell lymphoma. Subsequently, a proof-of-concept phase Ib study was established to evaluate the efficacy and safety of ibrutinib monotherapy followed by ibrutinib plus chemotherapy (DA-TEDDi-R) in this population [35]. Their results indicated that ibrutinib appeared to enhance the efficacy of chemotherapy and significantly improve the outcomes of PCNSL patients.

\section{Combination therapy studies contained ibrutinib for B-cell lymphoma}

Although ibrutinib monotherapy has potent efficacy and durable response in many subtypes of B-cell lymphoma, patients who can achieve a faster, deeper, and durable $C R$ remain a minority, especially in some aggressive cases. Ibrutinib combination regimens are undergoing exploration, however, the optional combination strategies remain controversial [36-38]. Table 2 lists the current results of various combination strategies contained ibrutinib in B-cell lymphoma. 
Table 2 Clinical trials of ibrutinib combination strategies in B-cell lymphoma

\begin{tabular}{|c|c|c|c|c|c|c|c|}
\hline & $\begin{array}{l}\text { Therapeutic } \\
\text { regimens }\end{array}$ & Study (year) & Disease & Phase & Study details & Efficacy & Refs \\
\hline \multirow{7}{*}{$\begin{array}{l}\text { Ibrutinib-Anti- } \\
\text { CD20 Monoclo- } \\
\text { nal Antibody }\end{array}$} & \multirow[t]{4}{*}{$\begin{array}{l}\text { Ibrutinib-Rituxi- } \\
\text { mab (IR) }\end{array}$} & $\begin{array}{l}\text { Burger et al. } \\
\text { (2019) }\end{array}$ & R/R CLL & $\|$ & $\begin{array}{l}40 \text { pts with high- } \\
\text { risk CLL }\end{array}$ & $\begin{array}{l}\text { 36-month PFS } \\
86.9 \%\end{array}$ & [39] \\
\hline & & $\begin{array}{l}\text { Burger et al. } \\
\text { (2019) }\end{array}$ & CLL & NA & $\begin{array}{l}208 \text { pts, } 181 \\
\text { pts with R/R } \\
\text { CLL, 27 TN pts } \\
\text { with high-risk } \\
\text { disease }\end{array}$ & $\begin{array}{l}\text { 36-month ORR } \\
92 \% \text {, PFS } 86.9 \%\end{array}$ & [34] \\
\hline & & Jain et al. (2017) & $\mathrm{R} / \mathrm{R} \mathrm{MCL}$ & $\|$ & $50 \mathrm{pts}$ & $\begin{array}{l}\text { ORR 88\%, CR 58\%, } \\
\text { PR 30\% }\end{array}$ & {$[42]$} \\
\hline & & $\begin{array}{l}\text { Dimopoulos et al. } \\
\text { (2018) }\end{array}$ & WM & III & 150 pts & $\begin{array}{l}\text { MRR 72\%, } \\
30-\text { month PFS } \\
82 \%\end{array}$ & [44] \\
\hline & $\begin{array}{l}\text { Ibrutinib-Obinu- } \\
\text { tuzumab }\end{array}$ & $\begin{array}{l}\text { Moreno et al. } \\
\text { (2019) }\end{array}$ & TN CLL & III & $116 \mathrm{pts}$ & $\begin{array}{l}\text { ORR 88\%, CR 19\%, } \\
\text { 30-month PFS } \\
79 \%\end{array}$ & [36] \\
\hline & $\begin{array}{l}\text { Ibrutinib-Ofatu- } \\
\text { mumab }\end{array}$ & $\begin{array}{l}\text { Jaglowski et al. } \\
\text { (2015) }\end{array}$ & $\mathrm{CLL}$ & $\mid \mathrm{b} / \mathrm{|l}$ & $\begin{array}{l}66 \text { pts, ibrutinib } \\
\text { lead-in (group } \\
\text { 1), concurrent } \\
\text { start (group 2), } \\
\text { or ofatumumab } \\
\text { lead-in (group } \\
\text { 3) }\end{array}$ & $\begin{array}{l}\text { ORR were } 100 \% \\
79 \% \text { and } 71 \% ; \\
12 \text {-month PFS } \\
89 \%, 85 \%, 75 \% \\
\text { in group } 1 \sim 3 \\
\text { respectively }\end{array}$ & {$[37]$} \\
\hline & $\begin{array}{l}\text { Ibrutinib-Ublitux- } \\
\text { imab }\end{array}$ & $\begin{array}{l}\text { Sharman et al. } \\
(2017)\end{array}$ & R/R CLL & $\|$ & $45 \mathrm{pts}$ & $\begin{array}{l}\text { 6-month ORR } \\
\text { 88\%, pts with } \\
\text { high-risk ORR } \\
\text { 95\% }\end{array}$ & {$[38]$} \\
\hline \multirow[t]{10}{*}{$\begin{array}{l}\text { Ibrutinib-Chemo- } \\
\text { immunotherapy }\end{array}$} & \multirow[t]{3}{*}{ Ibrutinib-BR } & Fraser et al. (2019) & $\mathrm{R} / \mathrm{RCLL}$ & $\mid I I$ & $289 \mathrm{pts}$ & $\begin{array}{l}\text { 36-month PFS } \\
68 \% \text {, OS } 81.6 \%\end{array}$ & {$[45]$} \\
\hline & & $\begin{array}{l}\text { Brown et al. } \\
\text { (2015) }\end{array}$ & R/R CLL & $\mathrm{Ib}$ & $30 \mathrm{pts}$ & $\begin{array}{l}\text { ORR } 93.3 \% \text {, CR } \\
40 \% \text {, OS } 74 \% \\
\text { PFS } 86.3 \%\end{array}$ & {$[46]$} \\
\hline & & $\begin{array}{r}\text { Chanan-Khan } \\
\text { et al. (2016) }\end{array}$ & $\mathrm{R} / \mathrm{RCLL}$ & III & $289 \mathrm{pts}$ & $\begin{array}{l}\text { ORR } 83 \%, \text { CR10\%, } \\
\text { PFS 79\% }\end{array}$ & {$[48]$} \\
\hline & \multirow[t]{3}{*}{ Ibrutinib-FCR } & $\begin{array}{l}\text { Davids et al. } \\
\text { (2019) }\end{array}$ & $C L L$ & $\|$ & $\begin{array}{l}85 \text { pts, } 5 \% \text { del17p, } \\
4 \% \text { TP53 muta- } \\
\text { tions, } 2 \text { pts with } \\
\text { both }\end{array}$ & $\begin{array}{l}\text { 16.5-month CR } \\
33 \%\end{array}$ & {$[42]$} \\
\hline & & $\begin{array}{l}\text { Brown et al. } \\
\text { (2015) }\end{array}$ & $\mathrm{R} / \mathrm{RCLL}$ & $\mathrm{Ib}$ & 3 pts & $\begin{array}{l}\text { ORR } 100 \%, \text { CR } \\
67 \%, \text { PFS } 70.3 \%\end{array}$ & {$[46]$} \\
\hline & & $\begin{array}{l}\text { Shanafelt et al. } \\
\text { (2019) }\end{array}$ & CLL & III & $\begin{array}{l}354 \text { pts to IR } \\
\text { group, } 175 \\
\text { pts to the FCR } \\
\text { group }\end{array}$ & $\begin{array}{l}\text { 33.6-month PFS } \\
89.4 \% \text { vs. } 72.9 \% \\
\text { OS } 98.8 \% \text { vs. } \\
91.5 \%\end{array}$ & [48] \\
\hline & Ibrutinib-R-ICE & $\begin{array}{l}\text { Sauter et al. } \\
\quad(2018)\end{array}$ & DLBCL & I & 21 pts & $\begin{array}{l}\text { ORR 90\%, CR 55\%, } \\
\text { PR 35\% }\end{array}$ & [49] \\
\hline & DA-TEDDI-R & $\begin{array}{l}\text { Lionakis et al. } \\
\text { (2017) }\end{array}$ & PCNSL & $\mathrm{Ib}$ & $18 \mathrm{pts}$ & ORR 86\% & {$[35]$} \\
\hline & Ibrutinib-R-CHOP & $\begin{array}{l}\text { Younes et al. } \\
\text { (2014) }\end{array}$ & $\mathrm{NHL}$ & $\mathrm{Ib}$ & $32 p t s$ & ORR 94\% & {$[50]$} \\
\hline & $\begin{array}{l}\text { Ibrutinib-R-HD- } \\
\text { MTX }\end{array}$ & $\begin{array}{l}\text { Grommes et al. } \\
\text { (2019) }\end{array}$ & R/R CNSL & lb & 15 pts & $\begin{array}{l}\text { 19.7-month ORR } \\
80 \% \text {, CR 53.3\%, } \\
\text { PR 26.7\% }\end{array}$ & {$[51]$} \\
\hline
\end{tabular}


Table 2 (continued)

\begin{tabular}{|c|c|c|c|c|c|c|c|}
\hline & $\begin{array}{l}\text { Therapeutic } \\
\text { regimens }\end{array}$ & Study (year) & Disease & Phase & Study details & Efficacy & Refs. \\
\hline \multirow[t]{11}{*}{$\begin{array}{l}\text { Ibrutinib-Biotarget } \\
\text { Agents }\end{array}$} & $\begin{array}{l}\text { Ibrutinib-Rituxi- } \\
\text { mab-Lenalido- } \\
\text { mide }\end{array}$ & Ujjani et al. (2018) & R/R CLL & I & $12 \mathrm{pts}$ & $\begin{array}{l}\text { ORR 67\%, } \\
\text { 12-month PFS } \\
83 \%\end{array}$ & {$[62]$} \\
\hline & & $\begin{array}{l}\text { Jerkeman et al. } \\
\text { (2018) }\end{array}$ & $\mathrm{R} / \mathrm{R} \mathrm{MCL}$ & $\|$ & 50 pts & $\begin{array}{l}\text { ORR 76\%, CR 56\%, } \\
\text { PR 20\% }\end{array}$ & [2] \\
\hline & & Ujjani et al. (2016) & $\mathrm{FL}$ & I & $22 \mathrm{pts}$ & $\begin{array}{l}\text { ORR 95\%, } \\
\text { 12-month PFS } \\
80 \%\end{array}$ & [63] \\
\hline & $\begin{array}{l}\text { Ibrutinib-Vene- } \\
\text { toclax }\end{array}$ & Jain et al. (2019) & TN CLL & $\|$ & $\begin{array}{l}80 \text { pts (untreated high-risk } \\
\text { and the median age was } \\
65 \text { years) }\end{array}$ & $\begin{array}{l}\text { CR or CR with } \\
\text { incomplete } \\
\text { count recovery } \\
88 \% \text {; 1-year PFS } \\
98 \% \text {, OS } 99 \%\end{array}$ & {$[60]$} \\
\hline & & Tam et al. (2018) & $\mathrm{R} / \mathrm{R} M C L$ & $\|$ & $\begin{array}{l}24 \text { pts, 50\% with TP53 muta- } \\
\text { tion, } 75 \% \text { had high-risk } \\
\text { prognostic score }\end{array}$ & CR $42 \%$ & [54] \\
\hline & $\begin{array}{l}\text { Ibrutinib-Veneto- } \\
\text { clax-Obinutu- } \\
\text { zumab }\end{array}$ & $\begin{array}{l}\text { Rogers et al. } \\
\quad(2018)\end{array}$ & $\mathrm{R} / \mathrm{R} C L \mathrm{~L}$ & $\mathrm{lb}$ & $12 \mathrm{pts}$ & ORR $92 \%$, CR $42 \%$ & {$[55]$} \\
\hline & $\begin{array}{l}\text { Ibrutinib-Palbo- } \\
\text { ciclib }\end{array}$ & $\begin{array}{l}\text { Martain et al. } \\
\text { (2019) }\end{array}$ & $\mathrm{MCL}$ & I & $27 \mathrm{pts}$ & $\begin{array}{l}\text { 25.6-month ORR } \\
\text { 67\%, CR 37\%, } \\
\text { PFS 59.4\% }\end{array}$ & [54] \\
\hline & $\begin{array}{l}\text { Ibrutinib-Umbral- } \\
\text { isib }\end{array}$ & $\begin{array}{l}\text { Davids et al. } \\
\text { (2019) }\end{array}$ & R/R CLL & $\mathrm{lb}$ & $\begin{array}{l}21 \text { elder pts with more than } \\
\text { two previous therapies }\end{array}$ & $\begin{array}{l}\text { ORR } 90 \% \text {, CR 29\%, } \\
\text { PR } 62 \%\end{array}$ & [57] \\
\hline & & $\begin{array}{l}\text { Davids et al. } \\
\text { (2019) }\end{array}$ & $\mathrm{R} / \mathrm{R} M C L$ & $\mathrm{lb}$ & $\begin{array}{l}21 \mathrm{pts} \text {, median age of } \\
68 \text { years }\end{array}$ & $\begin{array}{l}\text { ORR } 67 \% \text {, CR 19\%, } \\
\text { PR 48\% }\end{array}$ & [57] \\
\hline & $\begin{array}{l}\text { Ibrutinib-Umbral- } \\
\text { isib-Ublituxi- } \\
\text { mab }\end{array}$ & $\begin{array}{l}\text { Nastoupil et al. } \\
\text { 2019) }\end{array}$ & $C L L$ & I & $46 \mathrm{pts}$ & ORR $84 \%$ & [58] \\
\hline & $\begin{array}{l}\text { Ibrutinib- } \\
\text { Nivolumab }\end{array}$ & $\begin{array}{l}\text { Younes et al. } \\
\text { (2019) }\end{array}$ & $\mathrm{NHL}$ & $1 / 2 a$ & $141 \mathrm{pts}$ & $\begin{array}{l}\text { ORR, high-risk } \\
\text { CLL/SLL 61\%, } \\
\text { FL 33\%, DLBCL } \\
36 \%\end{array}$ & [59] \\
\hline
\end{tabular}

Pts, Patients; CLL/SLL, Chronic lymphocytic leukemia/small lymphocytic lymphoma; WM, Waldenstroms macroglobulinemia; MCL, Mantle cell lymphoma; MZL, PFS, Progression-free survival; PR, partial response; CR, Complete response; ORR, Overall response rate; MRR, Major response rate; OS, Overall survival; R/R, Relapsed/ refractory; TN, Treatment-native; FCR, Fludarabine combined with cyclophosphamide and rituximab; R-ICE, Rituximab, ifosfamide, carboplatin, etoposide; R-CHOP, Rituximab plus cyclophosphamide, doxorubicin, vincristine, prednisone; R-HD-MTX, High-dose methotrexate; High-risk, Pts with del17p, del11q or with TP53 mutations

\section{Ibrutinib with anti-CD20 monoclonal antibody and chemoimmunotherapy}

In the beginning, many researchers combined rituximab (the first-generation anti-CD20 monoclonal antibody) with ibrutinib to investigate if the patients with CLL/SLL can benefit from this combination therapy. Burger et al. conducted a randomized single-center trial of ibrutinib single-agent versus ibrutinib plus rituximab (IR) in 208 (181 R/R and 27 NT diseases) patients with high-risk ( $17 \mathrm{p}$ - or TP53 mutation) CLL. After a median follow-up of 36 months, the PFS was $86 \%$ and $86.9 \%$ in the ibrutinib and IR group, respectively. The results from subsequent multicenter trials also proved that IR could not improve
PFS although these patients exhibited faster RR and low residual disease levels [39-41].

There were not many randomized and controlled studies comparing ibrutinib monotherapy or IR in MCL patients. Jain et al. reported a single-arm, phase II clinical trial of IR in patients with R/R MCL [42]. Twenty-nine of 50 (58\%) achieved CR and those with low ki 67 patients had more durable remissions. This result is relatively satisfied compared with that of $40 \%$ in our previous section for patients with R/R MCL who received ibrutinib monotherapy. However, a credible and comprehensive conclusion about the pros and cons of ibrutinib monotherapy or IR can not be drawn unless validated by larger samples, 


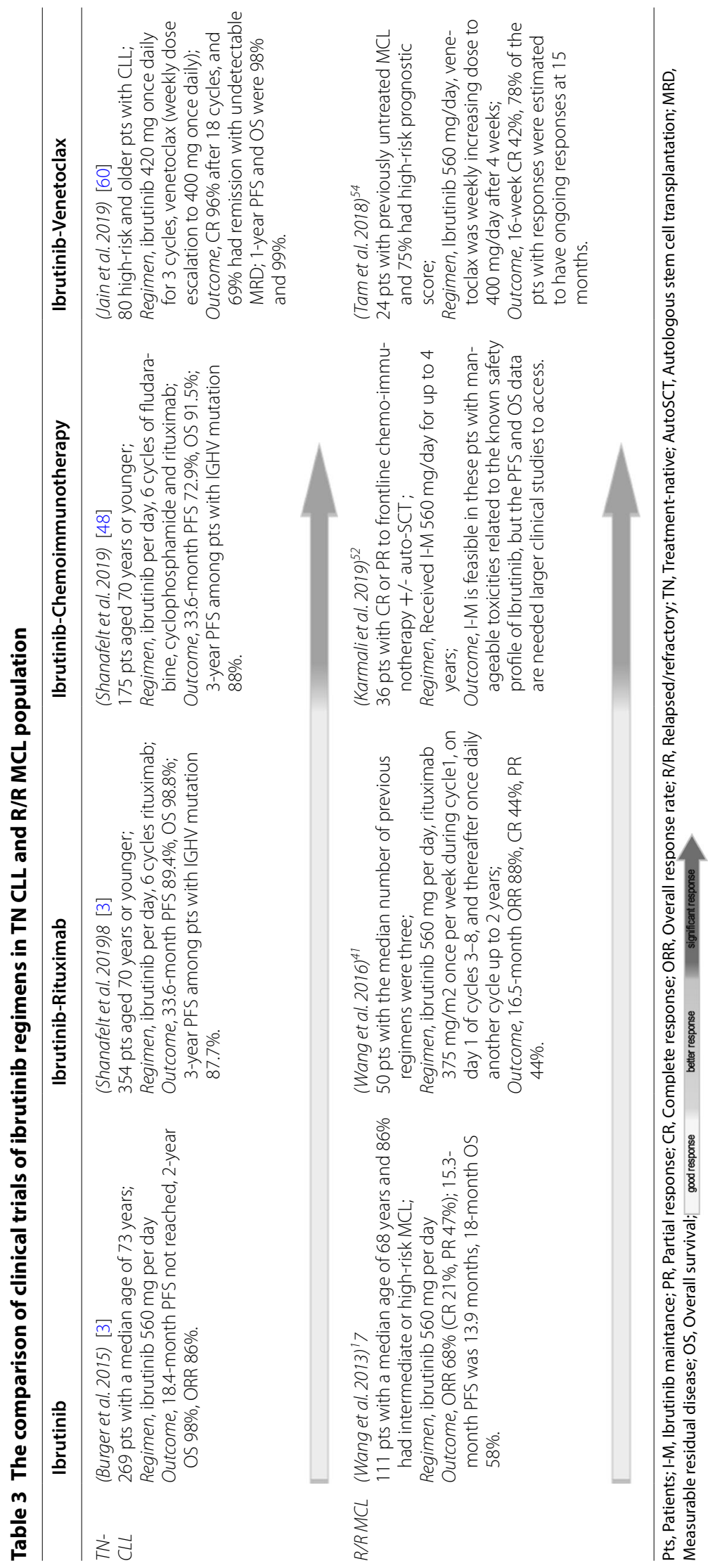


an accurate prognosis score combined with molecular biological analysis has been done.

Although quite an amount of studies have confirmed that IR is superior to rituximab monotherapy for patients with WM/LPL, there are not many controlled or head to head pilots to evaluate the difference between IR and single-agent ibrutinib [43, 44]. However, ibrutinib is at least an ideal choice, especially for elderly patients or those who are not eligible for intensive chemotherapy. Furthermore, patients with WM/LPL often suffer from amyloidosis, poor prognostic comorbidity with a high mortality rate, these patients often have a very poor response and tolerance to intensive chemotherapy.

There are also some studies to assess the RR of the combined chemoimmunotherapy strategy contained or not contained ibrutinib [45-52]. In 2016, ChanankKhan et al. compared the RR of ibrutinib combined with bendamustine and rituximab (IBR) and placebo-BR in 578 patients with R/R CLL/SLL (HELIOS trial) [53]. At a median follow-up of 17 months, PFS in the IBR group was significantly high than that of the placebo-BR group (not reached vs. 13.3 months). The AEs were similar in both groups. It is notable that patients with $17 \mathrm{p}$ - were excluded in the HELIOS trial. Although it seemed that the result from this randomized and double-blind trial indicated a significantly improved outcome with the IBR regimen, the data did not mean that IBR is superior to ibrutinib monotherapy because the molecular biological factors have not been incorporated into concern in this study. Therefore, ibrutinib monotherapy is still recommended as the first-line choice in patients with $R / R$ or NT CLL/SLL.

We should also realize the importance to make a balance between clinical effectiveness and cost in some developing countries, especially in those both agents can not be covered by medical insurance. Based on the existing studies, ibrutinib combining rituximab or chemoimmunotherapy might be unnecessary for some indolent cases.

\section{Ibrutinib with other biotarget agents}

As shown in Fig. 1b, BTK can regulate multiple cellular proliferation by activating multiple significant pathways, such as NF-kB, MAPK, NFAT, and mTOR pathway. It also indicated a cross-link of BCR-associated kinases (SYK, BTK, PKC, and PI3K) inhibitors. Therefore, if we combined ibrutinib with the above-associated bio target agents, a synergistic effect might be achieved [47, 54-59]. Here we chose CLL/SLL and MCL as examples and the comparison between ibrutinib monotherapy and combination regimens was listed in Table 3. Jain et al. conducted a preclinical investigation and confirmed that ibrutinib plus venetoclax (a BCL-2 inhibitor) had potential synergistic interaction as the first-line treatment for older patients with R/R CLL/SLL [60]. After 12 cycles of combined treatment, $88 \%$ of the patients achieved $\mathrm{CR}$ with undetectable minimal residual disease (MRD) and no added AEs. In addition to CLL/SLL, there were also quite a few studies in MCL and WM/LPL population which reported high RR with ibrutinib combined venetoclax [54, 61].

Lenalidomide has been proved to be effective in many subtypes of B-cell lymphoma [62, 63]. Jerkeman et al. combined ibrutinib, rituximab, and lenalidomide in the treatment of R/R MCL (PHLEMON trial) [2]. Before this trial, patients with $\mathrm{R} / \mathrm{R} M C L$ were usually treated with high-dose cytarabine contained regimen plus rituximab and followed by ASCT or allo-HSCT. All three drugs were given 12 cycles of 28 days and ibrutinib plus rituximab were used as maintenance therapy. At a median follow-up of 17.8 months, 38 patients had an overall response, including 28 (56\%) patients reached CR, and $10(20 \%)$ reached PR. This promising result proposed "chemo-free" feasibility for patients with R/R MCL. In the future, the treatment mode of MCL might be significantly altered due to the satisfied efficacy of multiple small molecular bio-target drugs combination.

Overall, different from ibrutinib with chemotherapy, ibrutinib combined with other bio target agents exhibited a powerful synergistic anti-tumor effect in B-cell lymphoma. In the future, more prospective, randomized, and controlled trials are needed to evaluate the feasibility of a "chemo-free" strategy in real-world investigations.

\section{Conclusions}

BTK is a central regulator of the BCR signaling pathway and targeting BTK has shown impressive efficacy in the treatment of various subtypes of B-cell malignancies. The advent of ibrutinib produced an epoch-making landscape with tolerated toxicity. Based on the existing studies, ibrutinib monotherapy has exhibited a powerful antitumor effect in almost all of the subtypes of B-cell lymphoma except for FL. Combination treatment contained ibrutinib has not been reached an agreement due to the chemotherapy-associated toxicity and the economic cost. In most of the investigations, it seems unnecessary to combine ibrutinib with the anti-CD20 antibody or chemotherapy, especially in indolent B-cell lymphoma. However, ibrutinib combined with other small molecular bio target agents might be a promising choice. In the future, more head-to-head comparisons and clinical trials are needed to assess the long-term efficacy and safety of the ibrutinib monotherapy or combination strategies to achieve much deeper and faster remission in the treatment of B-cell lymphoma. 


\begin{abstract}
Abbreviations
BCR: B cell receptor; BTK: Bruton's tyrosine kinase; RR: response rate; NHL: non-Hodgkin lymphoma; CLL/SLL: chronic lymphocytic lymphoma/small lymphocytic lymphoma; PCNSL: primary central nervous system lymphoma; FDA: Food and Drug Administration; MCL: mantle cell lymphoma; LPL: lymphoplasmacytic lymphoma; WM: Waldenstrom's macroglobulinemia; MZL: marginal zone lymphoma; RR: response rate; TN: treatment-native; DFS: disease-free survival; OS: overall survival; Allo-HSCT: allogeneic stem cell transplantation; TRM: transplantation-related morbidity; PFS: progression-free survival; ORR: overall response rate; CR: complete response; PR: partial response; ESMO: European Society of Medical Oncology; AEs: adverse events; ASCT: autologous stem cell transplantation; MYD88: myeloid differentiation primary response 88; FL: follicular lymphoma; EMZL: extranodal MZL; SMZL: splenic MZL; NMZL: nodal MZL; DLBCL: diffuse large B-cell lymphoma; ABC: activated B cell-like; GCB: germinal center B cell-like; PCNSL/SCNSL: primary or secondary central nervous system lymphoma; MTX: methotrexate; IR: rituximab; MRD: minimal residual disease.
\end{abstract}

\section{Acknowledgements}

Not applicable.

\section{Authors' contributions}

$C X, Q Q$, and $Q Z$ analyzed the literature. $L Z$ and $X W$ revised the manuscript. YJ wrote the manuscript. All authors read and approved the final manuscript.

\section{Funding}

This work was supported by research funding from Key Research and Development Program of Shandong Province (2019GSF108207); Science and Technology Development Project of Jinan (201907023).

\section{Availability of data and materials \\ Not applicable.}

\section{Ethics approval and consent to participate}

Not applicable.

\section{Consent for publication}

All participants have read and approved the manuscript.

\section{Competing interests}

The authors declare that they have no competing interests.

\section{Author details}

1 Department of Hematology, Shandong Provincial Hospital, Cheeloo College of Medicine, Shandong University, Jinan 250021, China. ${ }^{2}$ School of Medicine, Shandong University, Jinan 250012, Shandong, China. ${ }^{3}$ Department of Hematology, Shandong Provincial Hospital Affiliated to Shandong First Medical University, No.324, Jingwu Road, 250021 Jinan, Shandong, China.

\section{Received: 15 June 2020 Revised: 17 August 2020 Accepted: 24 August} 2020

Published online: 29 September 2020

\section{References}

1. Jones J, Mato A, Coutre S, Byrd JC, Furman RR, Hillmen P, et al. Evaluation of 230 patients with relapsed/refractory deletion $17 p$ chronic lymphocytic leukaemia treated with ibrutinib from 3 clinical trials. Br J Haematol. 2018;182(4):504-12.

2. Jerkeman M, Eskelund CW, Hutchings M, Raty R, Wader KF, Laurell A, et al. Ibrutinib, lenalidomide, and rituximab in relapsed or refractory mantle cell lymphoma (PHILEMON): a multicentre, open-label, single-arm, phase 2 trial. Lancet Haematol. 2018;5(3):e109-16.

3. Burger JA, Tedeschi A, Barr PM, Robak T, Owen C, Ghia P, et al. Ibrutinib as initial therapy for patients with chronic lymphocytic leukemia. N Engl J Med. 2015;373(25):2425-37.

4. Lee HJ, Gallardo M, Ma H, Zhang X, Larsson CA, Mejia A, et al. p53-independent ibrutinib responses in an Emu-TCL1 mouse model demonstrates efficacy in high-risk CLL. Blood Cancer J. 2016;6:e434.
5. Jain N. Selecting frontline therapy for CLL in 2018. Hematology Am Soc Hematol Educ Program. 2018;2018(1):242-7.

6. Grommes C, Pastore A, Palaskas N, Tang SS, Campos C, Schartz D, et al. Ibrutinib Unmasks Critical Role of Bruton Tyrosine Kinase in Primary CNS Lymphoma. Cancer Discov. 2017;7(9):1018.

7. Ponader S, Burger JA. Bruton's tyrosine kinase: from X-linked agammaglobulinemia toward targeted therapy for B-cell malignancies. J Clin Oncol. 2014;32(17):1830-9.

8. Zi F, Yu L, Shi Q, Tang A, Cheng J. Ibrutinib in CLL/SLL: From bench to bedside (Review). Oncol Rep. 2019;42(6):2213-27.

9. Hallek M, Fischer K, Fingerle-Rowson G, Fink AM, Busch R, Mayer J, et al. Addition of rituximab to fludarabine and cyclophosphamide in patients with chronic lymphocytic leukaemia: a randomised, open-label, phase 3 trial. Lancet. 2010;376(9747):1164-74.

10. Strati P, Keating MJ, O'Brien SM, Ferrajoli A, Burger J, Faderl S, et al. Outcomes of first-line treatment for chronic lymphocytic leukemia with $17 \mathrm{p}$ deletion. Haematologica. 2014;99(8):1350-5.

11. Byrd JC, Furman RR, Coutre SE, Flinn IW, Burger JA, Blum KA, et al. Targeting BTK with ibrutinib in relapsed chronic lymphocytic leukemia. N Engl J Med. 2013;369(1):32-42.

12. O'Brien S, Jones JA, Coutre SE, Mato AR, Hillmen P, Tam C, et al. Ibrutinib for patients with relapsed or refractory chronic lymphocytic leukaemia with 17p deletion (RESONATE-17): a phase 2, open-label, multicentre study. Lancet Oncol. 2016;17(10):1409-18.

13. Byrd JC, Furman RR, Coutre S, Flinn IW. Up to 7 years of follow-up of single-agent ibrutinib in the phase 1b/2 PCYC-1 102 trial of first line and relapsed/refractory patients with chronic lymphocytic leukemia/small lymphocytic lymphoma. Blood. 2018;132(Supplement 1):3133.n

14. Byrd JC, Brown JR, O'Brien S, Barrientos JC, Kay NE, Reddy NM, et al. Ibrutinib versus ofatumumab in previously treated chronic lymphoid leukemia. N Engl J Med. 2014;371(3):213-23.

15. O'Brien S, Furman RR, Coutre SE, Sharman JP, Burger JA, Blum KA, et al. Ibrutinib as initial therapy for elderly patients with chronic lymphocytic leukaemia or small lymphocytic lymphoma: an open-label, multicentre, phase 1b/2 trial. Lancet Oncol. 2014;15(1):48-58.

16. Cheah CY, Seymour JF, Wang ML. Mantle cell lymphoma. J Clin Oncol. 2016;34(11):1256-69.

17. Wang ML, Rule S, Martin P, Goy A, Auer R, Kahl BS, et al. Targeting BTK with ibrutinib in relapsed or refractory mantle-cell lymphoma. N Engl J Med. 2013;369(6):507-16.

18. Wang ML, Blum KA, Martin P, Goy A, Auer R, Kahl BS, et al. Long-term follow-up of MCL patients treated with single-agent ibrutinib: updated safety and efficacy results. Blood. 2015;126(6):739-45.

19. Dreyling M, Jurczak W, Jerkeman M, Silva RS, Rusconi C, Trneny M, et al. Ibrutinib versus temsirolimus in patients with relapsed or refractory mantle-cell lymphoma: an international, randomised, open-label, phase 3 study. Lancet. 2016;387(10020):770-8.

20. Robak T, Smolewski P, Robak P, Dreyling M. Mantle cell lymphoma: therapeutic options in transplant-ineligible patients. Leuk Lymphoma. 2019;60(11):2622-34.

21. Jeon YW, Yoon S, Min GJ, Park SS, Park S, Yoon JH, et al. Clinical outcomes for ibrutinib in relapsed or refractory mantle cell lymphoma in real-world experience. Cancer Med. 2019;8(16):6860-70.

22. Ghobrial IM, Xie W, Padmanabhan S, Badros A, Rourke M, Leduc R, et al. Phase II trial of weekly bortezomib in combination with rituximab in untreated patients with Waldenstrom Macroglobulinemia. Am J Hematol. 2010;85(9):670-4.

23. Treon P, Hunter R, Castillo J, Giampaolo M. Waldenström Macroglobulinemia. 2014;28(5):945-70.

24. Dimopoulos MA, Trotman J, Tedeschi A, Matous JV, Macdonald D, Tam C, et al. Ibrutinib for patients with rituximab-refractory Waldenstrom's macroglobulinaemia (iNNOVATE): an open-label substudy of an international, multicentre, phase 3 trial. The Lancet Oncology. 2017;18(2):241-50.

25. Treon SP, Cao Y, Xu L, Yang G, Liu X, Hunter ZR. Somatic mutations in MYD88 and CXCR4 are determinants of clinical presentation and overall survival in Waldenström macroglobulinemia. Blood. 2014;123(18):2791-6.

26. Treon SP, Xu L, Hunter Z. MYD88 Mutations and Response to Ibrutinib in Waldenstrom's Macroglobulinemia. N Engl J Med. 2015;373(6):584-6.

27. Treon SP, Tripsas CK, Meid K, Warren D, Varma G, Green R, et al. Ibrutinib in previously treated Waldenstrom's macroglobulinemia. N Engl I Med. 2015;372(15):1430-40. 
28. Noy A, de Vos S, Thieblemont C, Martin P, Flowers CR, Morschhauser F, et al. Targeting Bruton tyrosine kinase with ibrutinib in relapsed/refractory marginal zone lymphoma. Blood. 2017;129(16):2224-32.

29. Advani RH, Buggy JJ, Sharman JP, Smith SM, Boyd TE, Grant B, et al. Bruton tyrosine kinase inhibitor ibrutinib (PCl-32765) has significant activity in patients with relapsed/refractory B-cell malignancies. J Clin Oncol. 2013;31(1):88-94.

30. Bartlett NL, Costello BA, LaPlant BR, Ansell SM, Kuruvilla JG, Reeder CB, et al. Single-agent ibrutinib in relapsed or refractory follicular lymphoma: a phase 2 consortium trial. Blood. 2018;131(2):182-90.

31. Schmitz R, Wright GW, Huang DW, Johnson CA, Phelan JD, Wang JQ, et al. Genetics and pathogenesis of diffuse large B-Cell lymphoma. N Engl J Med. 2018;378(15):1396-407.

32. Wilson WH, Young RM, Schmitz R, Yang Y, Pittaluga S, Wright G, et al. Targeting $B$ cell receptor signaling with ibrutinib in diffuse large $B$ cell lymphoma. Nature medicine. 2015;21(8):922-6.

33. Low $\mathrm{S}, \mathrm{Han} \mathrm{CH}$, Batchelor TT. Primary central nervous system lymphoma. Ther Adv Neurol Disord. 2018;11:1756286418793562.

34. Grommes C, Pastore A, Palaskas N, Tang SS, Campos C, Schartz D, et al. Ibrutinib unmasks critical role of bruton tyrosine kinase in primary CNS lymphoma. Cancer Discov. 2017;7(9):1018-29.

35. Lionakis MS, Dunleavy K, Roschewski M, Widemann BC, Butman JA, Schmitz R, et al. Inhibition of B Cell Receptor Signaling by Ibrutinib in Primary CNS Lymphoma. Cancer Cell. 2017;31 (6):833-43. e5.

36. Moreno C, Greil R, Demirkan F, Tedeschi A, Anz B, Larratt L, et al. Ibrutinib plus obinutuzumab versus chlorambucil plus obinutuzumab in first-line treatment of chronic lymphocytic leukaemia (iLLUMINATE): a multicentre, randomised, open-label, phase 3 trial. Lancet Oncol. 2019;20(1):43-56.

37. Jaglowski SM, Jones JA, Nagar V, Flynn JM, Andritsos LA, Maddocks KJ, et al. Safety and activity of BTK inhibitor ibrutinib combined with ofatumumab in chronic lymphocytic leukemia: a phase $1 \mathrm{~b} / 2$ study. Blood. 2015;126(7):842-50.

38. Sharman JP, Farber CM, Mahadevan D, Schreeder MT, Brooks HD, Kolibaba KS, et al. Ublituximab (TG-1101), a novel glycoengineered anti-CD20 antibody, in combination with ibrutinib is safe and highly active in patients with relapsed and/or refractory chronic lymphocytic leukaemia: results of a phase 2 trial. Br J Haematol. 2017;176(3):412-20.

39. Burger JA, Sivina M, Jain N, Kim E, Kadia T, Estrov Z, et al. Randomized trial of ibrutinib vs ibrutinib plus rituximab in patients with chronic lymphocytic leukemia. Blood. 2019;133(10):1011-9.

40. Burger JA, Keating MJ, Wierda WG, Hartmann E, Hoellenriegel J, Rosin NY, et al. Safety and activity of ibrutinib plus rituximab for patients with highrisk chronic lymphocytic leukaemia: a single-arm, phase 2 study. Lancet Oncol. 2014;15(10):1090-9.

41. Wang ML, Lee H, Chuang H, Wagner-Bartak N, Hagemeister F, Westin J, et al. Ibrutinib in combination with rituximab in relapsed or refractory mantle cell lymphoma: a single-centre, open-label, phase 2 trial. Lancet Oncol. 2016;17(1):48-56.

42. Jain P, Romaguera J, Srour SA, Lee HJ, Hagemeister F, Westin J, et al. Four-year follow-up of a single arm, phase II clinical trial of ibrutinib with rituximab (IR) in patients with relapsed/refractory mantle cell lymphoma (MCL). Br J Haematol. 2018;182(3):404-11.

43. Papanota AM, Ntanasis-Stathopoulos I, Kastritis E, Dimopoulos MA, Gavriatopoulou M. Evaluating ibrutinib in the treatment of symptomatic Waldenstrom's macroglobulinemia. J Blood Med. 2019;10:291-300.

44. Dimopoulos MA, Tedeschi A, Trotman J, Garcia-Sanz R, Macdonald D, Leblond V, et al. Phase 3 Trial of Ibrutinib plus Rituximab in Waldenstrom's Macroglobulinemia. N Engl J Med. 2018;378(25):2399-410.

45. Fraser G, Cramer P, Demirkan F, Silva RS, Grosicki S, Pristupa A, et al. Updated results from the phase 3 HELIOS study of ibrutinib, bendamustine, and rituximab in relapsed chronic lymphocytic leukemia/small lymphocytic lymphoma. Leukemia. 2019;33(4):969-80.

46. Brown JR, Barrientos JC, Barr PM, Flinn IW, Burger JA, Tran A, et al. The Bruton tyrosine kinase inhibitor ibrutinib with chemoimmunotherapy in patients with chronic lymphocytic leukemia. Blood. 2015;125(19):2915-22.

47. Davids MS, Brander DM, Kim HT, Tyekucheva S, Bsat J, Savell A, et al. Ibrutinib plus fludarabine, cyclophosphamide, and rituximab as initial treatment for younger patients with chronic lymphocytic leukaemia: a single-arm, multicentre, phase 2 trial. Lancet Haematol. 2019;6(8):e419-28.

48. Shanafelt TD, Wang XV, Kay NE, Hanson CA, O'Brien S, Barrientos J, et al. Ibrutinib-Rituximab or Chemoimmunotherapy for Chronic Lymphocytic Leukemia. N Engl J Med. 2019;381(5):432-43.

49. Sauter CS, Matasar MJ, Schoder H, Devlin SM, Drullinsky P, Gerecitano J, et al. A phase 1 study of ibrutinib in combination with R-ICE in patients with relapsed or primary refractory DLBCL. Blood. 2018;131(16):1805-8.

50. Younes A, Thieblemont C, Morschhauser F, Flinn I, Friedberg JW, Amorim $\mathrm{S}$, et al. Combination of ibrutinib with rituximab, cyclophosphamide, doxorubicin, vincristine, and prednisone (R-CHOP) for treatment-naive patients with CD20-positive B-cell non-Hodgkin lymphoma: a nonrandomised, phase 1b study. Lancet Oncol. 2014;15(9):1019-26.

51. Grommes C, Tang SS, Wolfe J, Kaley TJ, Daras M, Pentsova EI, et al. Phase $1 \mathrm{~b}$ trial of an ibrutinib-based combination therapy in recurrent/refractory CNS lymphoma. Blood. 2019;133(5):436-45.

52. Karmali R, Abramson JS, Stephens DM, Barnes JA, Kaplan JB, Winter $\mathrm{JN}$, et al. Ibrutinib maintenance following induction for untreated mantle cell lymphoma (MCL): Initial safety report. J Clin Oncol. 2019;37(15_suppl):7542-.

53. Chanan-Khan A, Cramer P, Demirkan F, Fraser G, Silva RS, Grosicki S, et al. Ibrutinib combined with bendamustine and rituximab compared with placebo, bendamustine, and rituximab for previously treated chronic lymphocytic leukaemia or small lymphocytic lymphoma (HELIOS): a randomised, double-blind, phase 3 study. Lancet Oncol. 2016;17(2):200-11.

54. Tam CS, Anderson MA, Pott C, Agarwal R, Handunnetti S, Hicks RJ, et al. Ibrutinib plus venetoclax for the treatment of mantle-cell lymphoma. N Engl J Med. 2018;378(13):1211-23.

55. Rogers KA, Huang Y, Ruppert AS, Awan FT, Heerema NA, Hoffman $C$, et al. Phase $1 \mathrm{~b}$ study of obinutuzumab, ibrutinib, and venetoclax in relapsed and refractory chronic lymphocytic leukemia. Blood. 2018;132(15):1568-72.

56. Martin P, Bartlett NL, Blum KA, Park S, Maddocks K, Ruan J, et al. A phase 1 trial of ibrutinib plus palbociclib in previously treated mantle cell lymphoma. Blood. 2019;133(11):1201-4.

57. Davids MS, Kim HT, Nicotra A, Savell A, Francoeur K, Hellman JM, et al. Umbralisib in combination with ibrutinib in patients with relapsed or refractory chronic lymphocytic leukaemia or mantle cell lymphoma: a multicentre phase 1-1b study. Lancet Haematol. 2019;6(1):e38-47.

58. Nastoupil LJ, Lunning MA, Vose JM, Schreeder MT, Siddiqi T, Flowers CR, et al. Tolerability and activity of ublituximab, umbralisib, and ibrutinib in patients with chronic lymphocytic leukaemia and non-Hodgkin lymphoma: a phase 1 dose escalation and expansion trial. \&nbsp;Lancet Haematol. 2019;6(2):e100-9.n

59. Younes A, Brody J, Carpio C, Lopez-Guillermo A, Ben-Yehuda D, Ferhanoglu B, et al. Safety and activity of ibrutinib in combination with nivolumab in patients with relapsed non-Hodgkin lymphoma or chronic lymphocytic leukaemia: a phase 1/2a study. Lancet Haematol. 2019;6(2):e67-78.

60. Jain N, Keating M, Thompson P, Ferrajoli A, Burger J, Borthakur G, et al. Ibrutinib and venetoclax for first-line treatment of CLL. N Engl J Med. 2019;380(22):2095-103.

61. Paulus A, Akhtar S, Yousaf H, Manna A, Paulus SM, Bashir Y, et al. Waldenstrom macroglobulinemia cells devoid of BTK(C481S) or CXCR4(WHIMlike) mutations acquire resistance to ibrutinib through upregulation of BCl-2 and AKT resulting in vulnerability towards venetoclax or MK2206 treatment. Blood Cancer J. 2017;7(5):e565.

62. Ujjani C, Wang H, Skarbnik A, Trivedi N, Ramzi P, Khan N, et al. A phase 1 study of lenalidomide and ibrutinib in combination with rituximab in relapsed and refractory CLL. Blood Adv. 2018;2(7):762-8.nn

63. Ujjani CS, Jung S-H, Pitcher B, Martin P, Park SI, Blum KA. Phase 1 trial of rituximab, lenalidomide, and ibrutinib in previously untreated follicular lymphoma: Alliance A051103. Blood. 2016;128(21):2510-6.

\section{Publisher's Note}

Springer Nature remains neutral with regard to jurisdictional claims in published maps and institutional affiliations. 